\title{
Estamira e os frágeis limiares heterotópicos de resistência à psiquiatria enquanto estratégia de governo biopolítico das diferenças
}

\author{
Estamira and the fragiles heterotopic thresholds of resistance to psychiatry \\ as a biopolitical government strategy of differences
}

\author{
Silvio de Azevedo Soares ${ }^{\mathrm{a}}$
}

Resumo O objetivo deste trabalho é averiguar as probabilidades de resistência à psiquiatria - enquanto um dispositivo biopolítico de governo das diferenças - presente nas falas e na existência de Estamira, reproduzidas no documentário homônimo. Em termos metodológicos, utilizando as reflexões de Foucault e Butler, tomo Estamira como um documentário de inspiração genealógica, que permite a manifestação do discurso sujeitado e a apreensão das condições precárias da personagem, que se sujeita e resiste aos governos religioso, familiar - como instância de normalização disciplinar e psiquiátrica do sujeito - e médico-psiquiátrico de sua existência. Ao estabelecer-se em um lixão - enquanto um espaço heterotópico -, essa mulher classificada como louca e diagnosticada como esquizofrênica apresenta, de maneira paradoxal, uma resistência mais lúcida e crítica contra as investidas do poder psiquiátrico.

Palavras-chave Cinema documental. Estamira. Psiquiatria. Governo. Diferenças.

Abstract The objective of this work is to investigate the probabilities of resistance to psychiatry - as a biopolitical dispositive of government of differences - presente in the speeches and in the existence of Estamir, reproduced in the homonymous documentary. In methodological terms, using the reflections of Foucault and Butler, I take Estamira as a documentary of genealogical inspiration because it allows the manifestation of the subject speech and the apprehension of the precarious conditions of the character, which submits and resists to the religious, family - as instance of disciplinary and psychiatric normalization of the subject - and medical-psychiatric governments of its existence. When establishing herself in a dump - as a heterotopic space -, this woman classified as mad and diagnosed as schizophrenic presents, in a paradoxical

a Doutorando do Programa de Pós-Graduação em Ciências Sociais (PPGCS) da Universidade Estadual Paulista Júlio de Mesquita Filho (Unesp, Marília, Brasil) e pesquisador do Observatório de Segurança Pública (OSP) da Unesp < silvioaz@hotmail.com>. 
way, a more lucid and critical resistance against the assaults of psychiatric power. Keywords Documentary film. Estamira. Psychiatry. Government. Differences.

\section{INTRODUÇÃO}

“Eu, Estamira, não concordo com a vida.”

(Estamira, 2006)

"Eu penso que, de fato, a vontade de não ser governado é sempre a vontade de não ser governado assim, dessa forma, por elas, a esse preço." (Michel Foucault, O que é a crítica?, 1990)

O objetivo desse trabalho é analisar as possibilidades de resistência à psiquiatria - enquanto um dispositivo ${ }^{1}$ biopolítico de governo das diferenças - presentes nas falas, nas narrativas e na existência de Estamira Gomes de Souza - abordadas e veiculadas pelo documentário Estamira (2006), que relata a história dessa mulher, então com 63 anos, que sofre de distúrbios mentais e vive e trabalha no Aterro Sanitário de Jardim Gramacho, em Duque de Caxias, Rio de Janeiro. Para alcançar tal fim, compreendo aqui "diferença" a partir do quadro analítico desenvolvido por Michel Foucault: na modernidade ${ }^{2}$, os diferentes como aqueles sujeitos que estão aquém ou excedem, que escapam ou afrontam as normas disciplinares e biopolíticas. A diferença como o que não é norma(l).

Nesse sentido, a partir de uma revisão bibliográfica dos ditos e escritos genealógicos $^{3}$ de Foucault, apresento considerações sobre a emergência do biopoder - em suas interfaces disciplinar e biopolítica - e a constituição de uma sociedade da normalização enquanto condições de formação e consolidação de um governo dos anormais/dos diferentes. De forma específica, destaco como se procurou

1 Noção analítica utilizada por Foucault (2016c), dispositivo compreende toda uma rede heterogênea de práticas de poder, de discursos, de instituições, de leis, de normas, dentre outros elementos.

2 Para Foucault, a modernidade pode ser descrita: a) em um ângulo histórico, a partir do final do século XVIII; b) em uma perspectiva política, a partir do exercício do biopoder; c) em um ponto de vista epistêmico, com a constituição das ciências humanas (CASTRO, 2009, p. 301).

3 Estudiosos da obra de Foucault - como Machado (2016, p. 32) e Castro (2009, p. 264) - comumente dividem a sua trajetória intelectual, ainda que de forma insuficientemente precisa, em três períodos: uma arqueologia dos saberes, das regras de enunciação e de circulação dos discursos (anos 1960); uma analítica genealógica sobre os dispositivos de poder-saber que formam discursos e sujeitos (anos 1970); a fase ética de problematização do sujeito e das práticas através das quais o ser humano constituiu-se enquanto sujeito (anos 1980). 
efetivar um governo das diferenças através, entre outros dispositivos, da tecnologia médica-psiquiátrica (FoucAult, 2006d; 2010a).

Numa perspectiva metodológica, abordo o filme Estamira como um documentário de orientação genealógica (FoucAult, 1999; 2006a), que constrói um enquadramento de poder audiovisual (BUTLER, 2015) que possibilita a transmissão e, ao menos, a apreensão do discurso sujeitado e da precariedade de existência da personagem. De acordo com essa lógica, examino o conteúdo audiovisual do documentário, descrevendo e analisando - com o apoio também das considerações de Peter Pál Pelbart (2007) - as sujeições e as oposições de Estamira às tentativas de governo religioso, de governo familiar e de governo psiquiátrico de suas condutas.

A despeito do tom absoluto de sua fala: "Não vou ceder o meu ser a nada" (Estamira, 2006), quando está estabelecida no lixão - um espaço heterotópico (FoucAult, 2013a) -, Estamira se mostra em uma posição de resistência mais articulada contra o dispositivo psiquiátrico, aproximando-se de uma atitude crítica (FoucAult, 1990). Paradoxalmente, essa mulher rotulada de louca e diagnosticada como esquizofrênica, parece apresentar maior lucidez na crítica ao governo psiquiátrico de sua existência.

\section{PERSPECTIVA ANALÍTICA DO PODER EM FOUCAULT: PODER RELACIONAL, GOVERNO E RESISTÊNCIA}

Em inúmeras análises históricas realizadas na designada fase genealógica, Foucault descreve como as estratégias, os procedimentos e os controles de poder-saber se exerceram sobre a materialidade dos corpos humanos. Nessas análises, Foucault concebe o poder como algo que se exerce: é ato, é relacional - não constitui uma substância ou entidade que se possa ter, trocar, retomar. Como relação social, o poder funciona a partir de uma rede de interações entre corpos, discursos, saberes, práticas, onde os sujeitos - enquanto intermediários, não somente objetos de poder -, exercem, submetem-se ou resistem ao poder (Foucault, 1999, p. 32). Assim, não se tratam de relações de poder que se impõem de maneira unívoca, mas de múltiplas lutas, guerras e enfrentamentos - em dado contexto histórico e social - entre diferentes saberes, poderes e modos de concepção de sujeito.

Na modernidade, o poder deve ser compreendido não somente nas dimensões negativas de repressão, proibição e cerceamento, mas também como uma realidade positiva que constitui discursos e individualidades (Foucault, 1987, p. 172), que produz instrumentos de observação, registro, investigação e acúmulo de saber (Foucault, 1999, p. 45). 
Dessa maneira, em Foucault, o poder e o saber se implicam e se reforçam mutuamente: às múltiplas relações de poder que constituem e perpassam o corpo social, associam-se discursos de verdade específicos, isto é, saberes produzidos e postos em circulação pelos mecanismos de poder. Tais práticas de poder e discursos de saber, a partir de determinadas instituições - como escolas, hospícios, prisões, etc. -, engendram sujeitos e determinam as maneiras pelas quais os indivíduos se concebem e são compreendidos pelo corpo social - alunos, doentes mentais, delinquentes, etc.

No curso Segurança, território, população (2008), em uma espécie de deslocamento espiral no interior de seu quadro analítico ${ }^{4}$, Foucault passou a considerar o poder também como da ordem do governo, no sentido de direção de condutas de outro indivíduo ou de um grupo: poder que incita, induz, desvia, facilita ou dificulta, limita ou estende, obriga ou impede certos comportamentos e condutas (Foucault, 1995, p. 243). Neste sentido, afirma Foucault que o "traço distintivo do poder é que alguns homens podem mais ou menos determinar inteiramente a conduta de outros homens - mas nunca de maneira exaustiva ou coercitiva." (FoucAult, 2006c, p. 384, grifos colocados).

Dessa citação decorre uma terceira consideração à noção de poder em Foucault: enquanto relação em rede, o poder provoca possibilidades de resistência, de contra-conduta, de recusa às suas intenções (Foucault, 1995, p. 232; 2006c, p. 384). Daí a reciprocidade ontológica entre estratégias de poder e táticas de resistência - as relações de poder "só podem existir em função de uma multiplicidade de pontos de resistência: estes desempenham nas relações de poder, o papel de adversário, de alvo, de apoio, de saliência onde se agarrar." (FoucAult, 1985, p. 91).

\section{SOCIEDADE DA NORMALIZAÇÃO E A EMERGÊNCIA DE UM GOVERNO DOS ANORMAIS/ DAS DIFERENÇAS}

Entre fins do século XVII e meados do XIX, Foucault constata uma reconfiguração na estratégia geral de poder. Da preponderância de uma lógica de poder denominada soberania, que se exercia essencialmente no direito do soberano sobre os súditos de "causar a morte ou de deixar viver" (Foucault, 1985, p.148, grifos colocados), houve a passagem para a prevalência do biopoder que, tomando como

4 No curso de 1975-76, Em Defesa da Sociedade (1999), Foucault realiza uma autocrítica ao modelo binário da guerra enquanto princípio de análise das relações de poder (utilizado nos estudos anteriores citados). Tal modelo da guerra entre dois antagonistas seria insuficiente para compreender a multiplicidade das relações de poder, já que as codifica, de forma excessiva, como violência, enfrentamento, rivalidade (PELBART, 2017, p. 14). 
objeto o corpo e a vida do ser humano, caracteriza-se como "um poder de causar a vida ou devolver à morte" (FoucAult, 1985, p.150, grifos colocados).

Enquanto sistema de poder, o biopoder não se aplica exclusivamente ao governo considerado institucionalmente, mas ao funcionamento entrelaçado do saber e do poder em inúmeros âmbitos da sociedade moderna (CASTRO, 2009, p. 327). Dessa forma, através das dimensões do biopoder - a disciplina, individualizante; a biopolítica, massificante -, a vida humana foi inserida em uma série de mecanismos de poder que possuem como objetivos a maximização das forças individuais e a otimização da vida coletiva.

$\mathrm{Na}$ implementação das tecnologias disciplinares, Foucault (2010a, p. 43) destaca a elaboração de uma série de normas - de modelos considerados como "ótimos" - que, como mecanismos de poder, possuíam a finalidade de coerção e correção dos indivíduos e grupos nos diferentes domínios em que elas se aplicavam. A partir das normas, o olhar normalizador do exame - constituindo saberes como a psiquiatria, a criminologia, a pedagogia - compôs um sistema exaustivo de classificação e hierarquização das diferenças individuais - os "normais" e os "anormais", os “aptos" e os "inaptos".

Já na biopolítica, a vida - em sua multiplicidade de circunstâncias sociais foi reduzida à dimensão biológica de espécie humana (Foucault, 1999, p. 289) e circunscrita à noção de população enquanto o conjunto plural de corpos vivos (FouCAUlt, 2008, p. 28). Em sua interface biopolítica, o biopoder tomou, como objeto, os fenômenos biossociológicos da espécie humana como as doenças, a natalidade, a mortalidade. Tratava-se, assim, de buscar melhorar as condições de existência de uma população, procurando aumentar a vida, visando "intervir para fazer viver, e na maneira de viver, e no 'como' da vida” (Foucault, 1999, p. 295).

Para dar conta, em nível global e na fineza dos detalhes (Foucault, 2006b, p. 302), dos múltiplos domínios da vida, a biopolítica, por um lado, consolidou uma expansão e multiplicação das artes de $\operatorname{governar}^{5}$ (FouCAULT, 1990, p. 3): governo da população pela economia política, governo das crianças pelos professores, governo do indivíduo pela família, governo dos doentes pelo médico, governo dos ilegalismos pelo sistema prisional. Através de um neologismo, Foucault designa esse processo de desenvolvimento de inúmeros dispositivos específicos de governo e de

5 Emergência de inúmeras artes de governo que ocorreu a partir da generalização extra-religiosa do poder pastoral no século XV (Foucault, 1990). Em vários trabalhos (1990, 2006b, 2008), Foucault realiza uma genealogia do poder pastoral enquanto governo das condutas de todos e de cada um, bem como da apropriação e transformação dessa forma de governo pelo Estado moderno. 
saberes sobre a população de "governamentalidade" (Foucault, 2006b, p. 303). Por outro lado, a biopolítica levou também a uma organização e centralização estatal dos aparelhos de governo, a uma tendência de "estatização do biológico humano" (Foucault, 1999, p. 286), que implicou numa "governamentalização do Estado" (Foucault, 2006b, p. 384) como o processo no qual o Estado passou a coordenar os governos de múltiplos aspectos micropolíticos da vida.

Como discursos de saber da biopolítica, constituiu-se a demografia, a estatística, a economia política e a medicina social. Discursos que se ocupavam do conjunto da população e seus fenômenos e fundamentavam procedimentos de normalização - distintos da normalização disciplinar (FouCAult, 2008, p. 83) - que visavam coeficientes gerais normalmente esperados sobre a população e suas secções internas - como taxas de mortalidade e de morbidade de grupos específicos, de ocupações específicas que não colocassem em risco a vitalidade e a força produtiva de uma população.

Enquanto tecnologias que visavam fazer viver, pode-se considerar que, na efetivação da biopolítica ainda nos séculos XVIII e XIX, constituiu-se um governo das anomalias, das causas de "diminuição do tempo de trabalho, baixa de energias, custos econômicos" (Foucault, 1999, p. 290), das doenças como fatores de "morte permanente, que se introduz sorrateiramente na vida, a corrói perpetuamente, a diminui e a enfraquece" (Foucault, 1999, p. 291). Consequentemente, as incapacidades biológicas diversas foram assumidas como ameaças à vida e os doentes, os sujeitos na velhice e qualquer perigo interno em relação à segurança do conjunto - loucos, degenerados, criminosos, mendigos - foram tomados como diferenças a serem governadas, rejeitadas, expulsas e, no limite, deixadas morrer.

Dessa forma, no contexto de uma sociedade de normalização (Foucault, 1999, p. 302) que congrega as normalizações disciplinar e biopolítica, deixar morrer é resultado de uma gestão calculista da vida que, para maximizar a existência biológica de uma população, distribui “vivos em um domínio de valor e utilidade" (FouCAUlt, 1985, p. 157) e chega até mesmo a planejar e exigir a morte de outros.

Todavia, é necessário sublinhar que as análises de Foucault referem-se a uma sociedade de normalização e não a uma sociedade normalizada (CASTRO, 2009, p. 309). Ou seja, a normalização diz respeito ao modo de funcionamento e à finalidade do biopoder e, ainda que tenham atingido uma extensão considerável, os procedimentos de normalização nem por isso deram-se - ou se realizam atualmente - de forma absoluta, sem resistências, críticas e movimentos de luta. Existiram - e sucedem-se - fugas e restos às tentativas biopolíticas de totalização da massa de sujeitos à população. Ocorreram - e ainda se desenrolam - escapes 
às normas disciplinares e biopolíticas: a própria norma "traça a fronteira do que lhe é exterior - a diferença com respeito a todas as diferenças -, a anormalidade" (CAStro, 2009, p. 310). Efetivaram-se e realizam-se críticas e questões ao fenômeno da governamentalidade: como não ser governado dessa ou daquela forma? (FouCAult, 1990). Em suma, da consolidação de uma sociedade da normalização emergiu também um governo das diferenças, dos que resistem, insubordinam-se e escapam tanto às normas disciplinares quanto às biopolíticas.

\section{MEDICALIZAÇÃO PSIQUIÁTRICA E A CONSOLIDAÇÃO DE UM GOVERNO DOS ANORMAIS/DAS DIFERENÇAS}

Se as duas interfaces do biopoder não se exercem sobre o mesmo nível, todavia, articulam-se uma à outra. Foucault destaca (1999, 2010a) que a medicina e, entre as especialidades médicas, a psiquiatria são estratégias articuladas de normalização visto que buscaram efetuar, concomitantemente, o assujeitamento disciplinar do corpo-organismo e a regulação biopolítica dos processos biológicos de uma população.

Castro reforça que "a sociedade da normalização é uma sociedade fundamentalmente medicalizada" (2009, p. 310), uma sociedade na qual a medicina moderna, que emergiu nos fins do século XVIII, se alastrou e foi muito além da questão das enfermidades. Nessa perspectiva, numa série de trabalhos (2010b, 2016a, 2016b), Foucault descreve como a medicina moderna, em sua função política de normalização social, incumbiu-se de inúmeros domínios não estritamente patológicos: a) do conjunto de corpos compreendidos como força global do Estado; b) do meio urbano, incluindo a higiene pública, as condições de moradia, a localização dos bairros, a circulação de ar, água e miasmas; c) da força de trabalho, ocupando-se dos pobres e dos operários; d) da família, constituída como primeira instância da normalização dos sujeitos, e da infância, incluindo higiene, amamentação, vacinação, vestuário. Em outros termos, com o desenvolvimento da medicina moderna se estabeleceu uma ascendência médico-política de controle social sobre a população, suas secções internas e seu meio de existência, que foram enquadrados em uma série de prescrições normalizantes.

Nos cursos O Poder Psiquiátrico (1973-74) e Os Anormais (1974-75), Foucault realiza, de forma específica, a análise da psiquiatria como mecanismo de normalização social. Em O Poder Psiquiátrico (Foucault, 2006d), através de uma genealogia histórica do dispositivo psiquiátrico de poder-saber, o curso descreve como, desde os primeiros passos da psiquiatria asilar no início do século XIX, a loucura enquanto doença mental foi concebida como distúrbios em relação 
à conduta regular e normal de agir, querer, sentir e experimentar as paixões (FoucAult, 2006d, p. 443).

Nesse período, a família tornou-se parte dos objetos da psiquiatria ao ser identificada como uma das causas deflagradoras da loucura - devido às contrariedades e preocupações no seio familiar como as perdas financeiras e as separações. Essa generalização psiquiátrica sobre a família realizou-se de duas formas: como estratégia de medicalização disciplinar, patologizando questões familiares - como o leito conjugal, o quarto infantil, o vestuário, a alimentação - e como disciplinarização interna da família, através da adoção, por esta, de práticas como a vigilância sobre os filhos, o controle da postura, gestos, comportamentos das crianças. Dessa forma, a família passou a funcionar como uma das instâncias de identificação do sujeito psiquiatrizável: quando um sujeito escapava ao poder da família, era internado e posto sob as práticas do asilo que deveriam disciplinarizá-lo, para então retornar ao convívio com seus familiares.

Progressivamente, o discurso psiquiátrico da doença mental como desvio da conduta regular se generalizou para todos os dispositivos disciplinares. Na ocasião em que uma pessoa era incapaz de seguir a disciplina escolar, da oficina ou do exército, a psiquiatria intervinha como esquema de normalização e sujeição desse sujeito no interior dessas instituições. Enfim, a psiquiatria desempenhou o papel de disciplina para todos os indisciplináveis, de instância de controle de todas as instituições disciplinares, colocando "fora do circuito certo número de indivíduos inutilizáveis no aparelho de produção” (Foucault, 2006d, p. 140).

Já em Os Anormais (Foucault, 2010a), a partir de um ponto de vista extramanicomial, Foucault aborda a generalização social da psiquiatria, realizando uma genealogia da noção de anormalidade. Através dessa noção, a psiquiatria se afastou da loucura como doença mental e emergiu, nos anos 1840-1875, como dispositivo de poder-saber do anormal, como ciência dos desvios, das anomalias e de todas as desordens possíveis de conduta (Foucault, 2010a, p. 210).

O campo do anormal, como abordado no interior dessa nova psiquiatria de meados do século XIX, foi constituído, de forma não sincrônica, a partir de três elementos: a) o monstro humano como exceção jurídica e biológica: as deformidades congênitas, o hermafroditismo, os irmãos siameses; como exceção jurídica e moral: os crimes sem motivo; b) o indivíduo indisciplinado, entendido como incorrigível que escapava das normas disciplinares preliminares; c) a criança masturbadora, a partir da concepção da masturbação como causa potencial de uma série de doenças e distúrbios. 
Nessa nova psiquiatria do anormal encontra-se um duplo sentido da noção de norma. Por um lado, a norma entendida como regra social de conduta, como lei informal e princípio de conformidade social, oposta à desordem, à excentricidade, aos desvios morais e jurídicos. Por outro, baseada na medicina orgânica e na neurologia, a norma era compreendida como a regularidade funcional do organismo, em contraste ao mau funcionamento do corpo, ao patológico, ao organismo disfuncional. Por esse duplo jogo da norma, o anormal na ordem das condutas podia ser referido ao anormal na ordem do organismo.

Através da constituição do campo das anomalias, a psiquiatria se viu diante de um domínio muito mais extenso que o da doença mental. Das infrações e pequenos desvios em relação à lei até as irregularidades intrafamiliares, do domínio penal ao controle da família, "tudo o que é desordem, indisciplina, agitação, indocilidade, caráter recalcitrante, falta de afeto, etc., tudo isso pode ser psiquiatrizado" (FoucAult, 2010a, p. 138). Dessa forma, a psiquiatria se tornava operadora geral dos mecanismos de poder - como a família, a escola, a fábrica, o tribunal, a prisão, o Estado.

A partir da constituição da teoria da degenerescência ${ }^{6}$, a psiquiatria consolidou-se, então, não mais como dispositivo terapêutico de cura, mas como instrumento de defesa da sociedade contra os perigos internos - biológicos, psíquicos, morais que pudessem ameaçá-la (Foucault, 1999, p. 277). Desse caráter de defesa social na psiquiatria, despontou também um novo tipo de racismo, denominado por Foucault como racismo interno ${ }^{7}$, que se voltava, enquanto estratégia biopolítica de proteção biológica da espécie, contra os próprios membros do grupo, contra os indivíduos portadores de anomalias transmissíveis aos seus descendentes.

Enfim, dessa generalização social sustentada pela medicalização e psiquiatrização do anormal, a psiquiatria consolidou-se como instância disciplinar e biopolítica de governo das diferenças enquanto anomalias.

\section{PERSPECTIVA METODOLÓGICA}

O documentário Estamira (115 minutos), dirigido por Marcos Prado e lançado em 2006, narra a história de uma catadora de lixo de 63 anos, classificada como

6 A teoria da degenerescência, sistematizada pelo médico franco-austriáco Bénédict Morel (18091873), concebia as doenças mentais a partir da noção de degenerescências - os supostos desvios da natureza biológica original do homem, a progressiva degeneração mental hereditária entre as gerações.

7 No curso Em defesa da sociedade (1999), Foucault descreve como esse racismo interno transformou-se em um mecanismo que permite ao Estado, no biopoder, reativar o direito soberano de matar ou expor à morte - o anormal, o desviante, o incorrigível, os que podem constituir riscos ao futuro da sociedade e da espécie humana. 
portadora de transtornos mentais, que vive e trabalha há mais de 20 anos em um aterro sanitário em Duque de Caxias, Rio de Janeiro. A partir de uma série de incursões no aterro desde 1994, das quais surgiu o ensaio fotográfico Jardim Gramacho (PRADO, 2004), o diretor conta que, em 2000, encontrou, conheceu, fotografou Estamira e, de certa forma, recebeu sua permissão para gravar o documentário: "Um dia, tempos depois de conhecê-la, ela me perguntou se eu sabia qual era a minha missão. Antes que eu respondesse, Estamira disse: 'a sua missão é revelar a minha missão'." (PRADO, 2004, p. 9, grifos colocados).

Procuro aqui compreender o documentário Estamira a partir de algumas considerações realizadas por Foucault e Judith Butler. Em A vida dos homens infames (2006a), Foucault analisa fragmentos de arquivos de finais do século XVII e início do XVIII referentes às pequenas infâmias cometidas por indivíduos de pouca importância em suas modestas vidas - blasfemos de pequena relevância, errantes, desocupados, homossexuais, alcoólatras, etc.. Devido a petições ao rei, por parte de familiares, do pároco local, de vizinhos, etc., esses insignificantes desvios e infâmias foram alvos de intervenções de poder e de registros em dossiês e arquivos. Tal poder que se tombou sobre essas existências produziu efeitos paradoxais: por um lado, através dessas poucas frases sobre elas lançadas, foram condenadas ao internamento, ao calabouço ou à morte; por outro, tais vidas sobreviveram por séculos graças aos rastros escritos - ainda que breves e obscuros - legados justamente por esse contato com o poder.

De maneira análoga, busco compreender o documentário produzido sobre Estamira também como resultado de uma intervenção de poder que, embora com efeitos distintos aos casos citados por Foucault, permitiu igualmente o registro de sua pequena infâmia. Nesse sentido, a produção do filme documental envolve procedimentos de poder como a perspectiva e o posicionamento de câmera do diretor - "não podemos garantir que o que vemos seja exatamente o que teríamos visto se estivéssemos presentes ao lado da câmera" (Nichols, 2008, p. 19) - a edição com os cortes, seleção e montagem das cenas (BAZIN, 1983) e a construção de uma impressão de autenticidade daquilo que é reproduzido (Nichols, 2008).

No entanto, apesar de todas as operações de poder intrínsecas à produção cinematográfica e que atravessam as falas e o corpo de Estamira, o documentário ainda lhe permite veicular sua fala, seu grito e sua experiência e, dessa forma, expandir sua potência de resistência e transgressão. Nesse sentido, com base na concepção de genealogia de Foucault (1999) - "ser o discurso daqueles que não têm a glória, ou daqueles que a perderam e se encontram agora, por uns tempos talvez, mas por muito tempo decerto, na obscuridade e no silêncio" (FoucAult, 1999, 
p. 82) -, entendo Estamira como um documentário de inspiração genealógica, visto que possibilita a emergência e a veiculação dos discursos sujeitados, das contracondutas que se insurgem contra certas disposições de poder.

Reforçando essa concepção de cinema genealógico e de documentário de contraconduta presente em Estamira, tomo também as reflexões de Butler ${ }^{8}$ (2015) sobre os enquadramentos de poder. Segundo a filósofa estadunidense, a apreensão, o conhecimento inteligível ${ }^{9}$ e o reconhecimento do outro em sua vida e em sua precariedade - enquanto condição política e relacional de fragilidade da existência ocasionada por fatores como as violências, as enfermidades, a miséria - são delineados, em procedimentos de poder, por enquadramentos visuais e discursivos. Tais enquadramentos audiovisuais operam como molduras que restringem e ao mesmo tempo configuram o nosso olhar e a nossa interpretação do que é apresentado (Butler, 2015, p. 14). Por esse ângulo, concebo o documentário Estamira como um enquadramento que proporciona na emergência e transmissão do discurso da personagem, no mínimo, a apreensão da precariedade de sua existência.

Dessa forma, considerando que o documentário, a despeito de todas as intervenções de poder, permite a Estamira dizer o que é por si, sem se aprisionar apenas ao discurso do conhecimento médico-psiquiátrico, procuro analisar o conteúdo do filme, as falas de Estamira e as suas condições de existência no lixão - que, em parte, ela teria construído em sua tentativa de resistência aos governos religioso, familiar e psiquiátrico das suas anomalias/diferenças.

\section{"VOCÊS É COMUM. EU NÃO SOU COMUM"}

O documentário aborda cenas e passagens da existência cotidiana de Estamira entre 2000 e 2004 - período contemporâneo à implementação e à consolidação da Reforma Psiquiátrica no Brasil (FONTE, 2013). Data de abril de 2001 a aprovação da lei federal $n^{\circ}$ 10.216, o marco legal da Reforma Psiquiátrica brasileira, resultado - em parte - da luta antimanicomial travada nas duas décadas anteriores por doentes e seus familiares em conjunto com trabalhadores da saúde mental (AMARAnte, 1998). Essa legislação tornou-se a referência da política nacional de serviços psiquiátricos, consolidando a reorientação da prática psiquiátrica no país através de propostas de fechamentos de manicômios e a implantação, nos anos

8 Apesar das diferenças entre a problemática do reconhecimento (com as possibilidades inerentes de qualificação da vida como vivível) proposta por Butler (2015) e a questão da identificação singular através das relações de poder que tombam sobre o sujeito, descrita por Foucault (2006a).

9 Butller (2015) realiza uma distinção entre apreensão e conhecimento: apreender implicar reconhecer o outro por uma forma não conceitual de conhecimento, através do sentir e do perceber (Butler, 2015, p. 18). 
seguintes, de serviços substitutivos de atenção ambulatorial aos doentes mentais, como os Centros de Atenção Psicossocial (CAPS).

As primeiras cenas do documentário, em preto e branco e acompanhadas de uma música em tom lamurioso, apresenta-nos a área externa de um simples barraco, coberto de telhas de zinco e com paredes de papelão e lona. Ao seu redor, perambulam cachorros. Ao longo de outras passagens, o documentário retrata o interior dessa morada: garrafas vazias jogadas ao chão de terra batida, uma faca sem cabo, utensílios domésticos enferrujados, um enfeite em forma de lua pendente do teto, um boneco do Batman também como adorno, uma camisa do Flamengo pendurada na parede e um livro religioso, "O Reino de Deus, Nosso Iminente Governo Mundial”. Aqui reside Estamira, nesse barraco por ela construído a partir do que retirava do lixão em que trabalha há cerca de duas décadas: "Não caguei essa casa, não. Não foi cagada, não. Foi trabalhado, suado! Dia e noite e no sol e na lama." (Estamira, 2006).

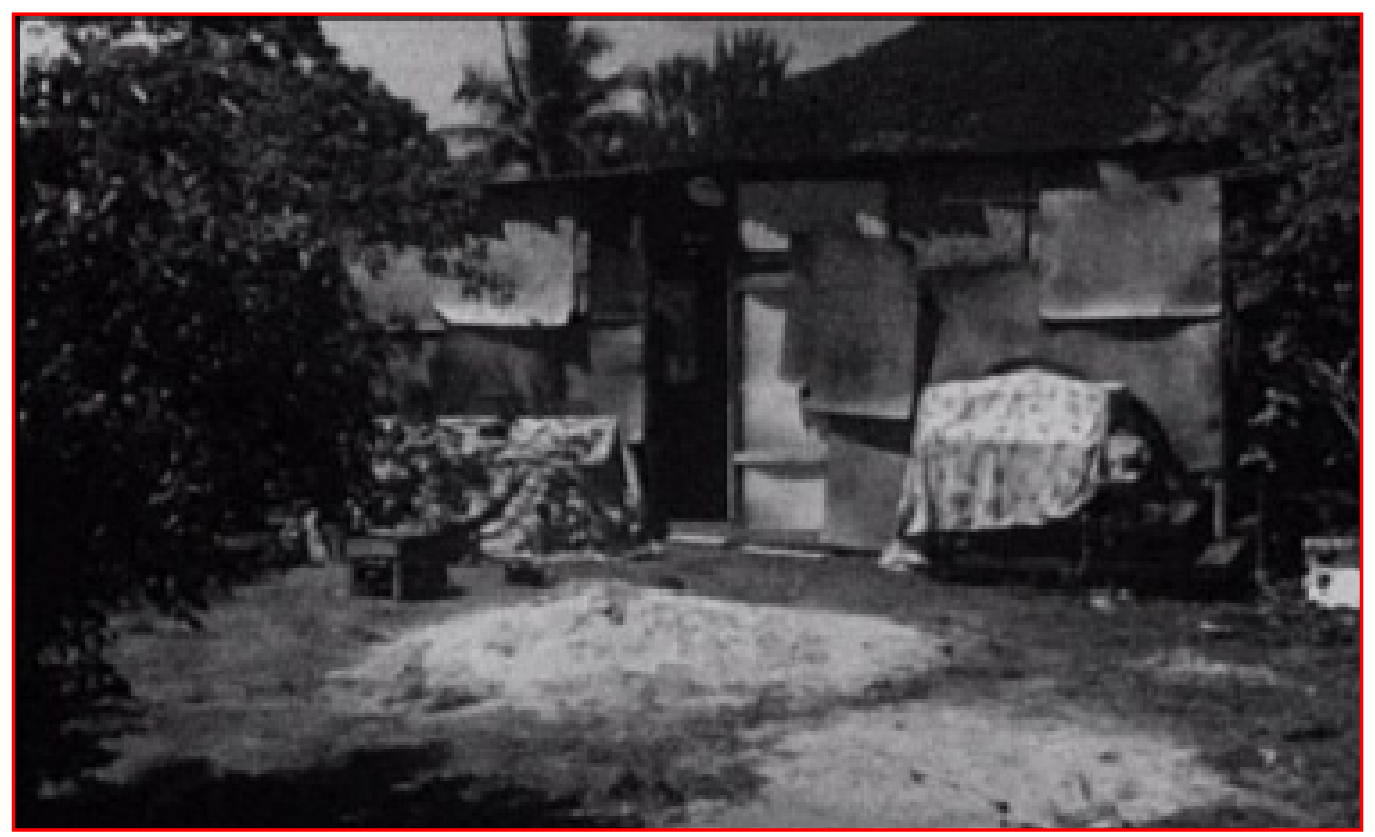

Figura 1. A casa de Estamira. Fonte: Estamira (2006).

A história dessa personagem - mulher, negra, miserável, diagnosticada como portadora de transtornos psíquicos, catadora de lixo, idosa - nos é então apresentada ao longo do filme. As toneladas de lixo que vemos chegar diariamente ao aterro correspondem ao peso das violências que tombaram sobre Estamira, narradas por ela e por seus três filhos, Hernani, Carolina e Maria Rita: órfã de pai aos dois anos, a mãe também classificada com transtornos mentais - "Coitada da minha mãe. Mais perturbada do que eu. Bem, eu sou perturbada, mas lúcida e sei 
distinguir a perturbação. Entendeu como é que é? E a coitada da minha mãe não conseguia. Mas também pudera, eu sou Estamira!" (Estamira, 2006) -, abusada sexualmente na infância, prostituída na pré-adolescência, traída duas vezes pelos maridos, vítima de violência doméstica, viveu na rua, foi estuprada, separada de uma filha contra a sua vontade, estuprada novamente.

Lamentavelmente, o pai da minha mãe é famílias de Ribeiro. Tudo polícia, tudo general, tudo não sei o quê, né? Ele é estrupador ${ }^{10}$. Ele estrupou a minha mãe. E fez coisa comigo. (...) É, e quando eu tinha 9 anos, eu pedi a ele pra comprar uma sandália pra mim... pra mim ir na festa que eu queria a sandália. Ele falou que só comprava se eu deitasse com ele. É, eu não gosto do pai da minha mãe, porque ele me pegou com 12 anos e me trouxe pra Goiás Velho. E... lá era um... era um bordel. É... Era um bordel, sabe, e eu prostituí lá. Era da filha dele. Aí, o pai do Hernani, ele me conheceu lá... aonde meu avô me deixou, lá no bordel... aí, eu já tinha 17 anos. E gostou demais de mim e deu no meu pé e arrumou uma casa e pôs eu dentro da casa. Mas o pai do Hernani, ele era muito cheio de mulher. Eu peguei e não aguentei. Larguei tudo dentro da casa e só apanhei o menino (EsTAMIRA, 2006).

Estamira e seus companheiros do lixão, como os modestos infames do final do século XVII, "pertencem a esses milhares de existências destinadas a passar sem deixar rastro" (FoucAult, 2006a, p. 207). Estamira não é vida reconhecida como vivível, isto é, distinguida em sua precariedade, contando com condições sociais e econômicas para viver. É vida em condição precária, sistematicamente negligenciada e privada de direitos, exposta de forma diferenciada às violações, à violência e à morte (BuTLER, 2015, p. 46).

No entanto, do que seria apenas fragilidade e impotência em Estamira - sua condição precária, seu transtorno psíquico, seu sofrimento - emerge uma força: "ao poder sobre a vida responde a potência da vida" (PELBART, 2007, p. 58). Essa biopotência de Estamira faz com que ela não seja somente, de maneira passiva, o resíduo das relações de poder. Com uma incrível acuidade, Estamira constitui uma subjetividade que ativamente resiste e busca subtrair-se às intervenções e insistências de governo religioso, familiar e psiquiátrico de suas condutas.

10 Na transcrição, mantive as falas de Estamira na forma como foram enunciadas. Alterar sua fala seria submetê-la aos enquadramentos de linguagem e de compreensão da, assim denominada, norma culta da gramática. 
Tal potência de vida é marcadamente notável em sua forma provocativa de dizer, de enunciar e em suas palavras proferidas: "fala descosturada, profética, poética, política, mística, metralhada” (PELBART, 2013, p. 4). Uma fala disparatada, recheada de neologismos, metáforas, devaneios que desafiam as nossas formas gramaticais de compreensão.

Trocadilo safado, canalha, assaltante de poder, manjado, desmascarado! Me trata como eu trato, que eu trato; me trata com o teu trato que eu te devolvo o teu trato. E faço questão de devolver em triplo. Onde já se viu uma coisa dessa?(...) Que Deus é esse? Que Jesus é esse, que só fala em guerra e não sei o quê? Não é ele que é o próprio trocadilo? Só para otários, pra esperto ao contrário, abobado, bestalhado. (Estamira, 2006).

O "trocadilo", esse neologismo criado por Estamira, corresponderia a uma espécie de entidade superior e maligna, responsável pelas coisas erradas do mundo, pela confusão na vida dos homens: "O trocadilo amaldiçoado, excomungado, hipócrita, safado, canalha, indigno, incompetente, sabe o que ele fez? Menti pros homem, seduz os homem, cega os homem. É, seduz os homem, enfeitiça os homem, depois joga no abismo!” (Estamira, 2006).

Pode-se obervar também na linguagem profética e na existência de Estamira um tom parresiástico ${ }^{11}$ como dos cínicos do período helenístico: uma fala provocadora, "Que Bíblia? Papel aceita até levar no banheiro. Papel é indefeso!"; um comportamento socialmente escandaloso e chocante - como na cena em que ela abaixa as vestes e aponta para o ventre indicando ao neto quem criou a mãe dele: "Não foi Deus que pariu sua mãe, não! Foi eu! Foi eu que pari! Aqui, ó! Aqui ó!” (Estamira, 2006); uma existência errante, despojada e sem dissimulações que lhe permite enunciar a sua verdade apesar dos riscos de incompreensão, descontentamento e ódio:

A minha missão é revelar, seja lá quem for, doa a quem doer. A verdade é nua e crua. Ninguém errado gosta da verdade. E eu via verdade. Eu faço o máximo

11 A noção de parrhesia da antiguidade grega pode ser traduzida como a fala franca, a coragem de enunciar a verdade em uma situação de risco. Foucault analisa, em seus trabalhos dos anos 1980 (2013b, 2017), os empregos e as práticas de parrhesia no mundo greco-romano (a passagem de uma parrhesia política para uma parrhesia ética). Sobre as aproximações entre Estamira e a prática parresiástica cínica pode se conferir o trabalho de Mansanera (2015). 
para não machucar quem quer que seja. Agora, se quem quer que seja sente-se machucado é porque está errado. (Estamira, 2006).

\section{"A ÚNICA SORTE QUE EU TIVE FOI CONHECER O SR. JARDIM GRAMACHO, O LIXÃO"}

Muitas passagens do documentário possuem, como cenário, o lixão de Jardim Gramacho, espaço de trabalho e convívio de Estamira. Localizado no município de Duque de Caxias e às margens da Baía de Guanabara, o aterro foi fechado em 2012 após mais de três décadas em operação. Esse lixão chegou a ser considerado o maior aterro da América Latina quando recebia, em média, mais de 7.000 toneladas de lixo por dia provenientes da cidade do Rio de Janeiro e contava com cerca de 1.600 catadores disputando o lixo (MARTín, 2017). No filme, há vários enquadramentos em que figuram as condições do lixão: montanhas de lixo e de sujeira; caminhões descarregando mais detritos; urubus pairando; poças de chorume; vários trabalhadores do local em vestes maltrapilhas garimpando, com as próprias mãos, os amontoados de lixo.

Eu não gosto de falar lixo, não, né? Mas vamos falar lixo. É cisco, né? É caldinho disso. É fruta, é carne, é plástico fino, é plástico grosso... É não sei o que lá mais... E aí vai azedando, é laranja, é isso tudo... E aí faz esse porque, sabe? E aí, imprensa, azeda, fica tudo danado e faz a pressão também. E aí vem o sol e esquenta e mais o fogo de baixo...(Estamira, 2006).

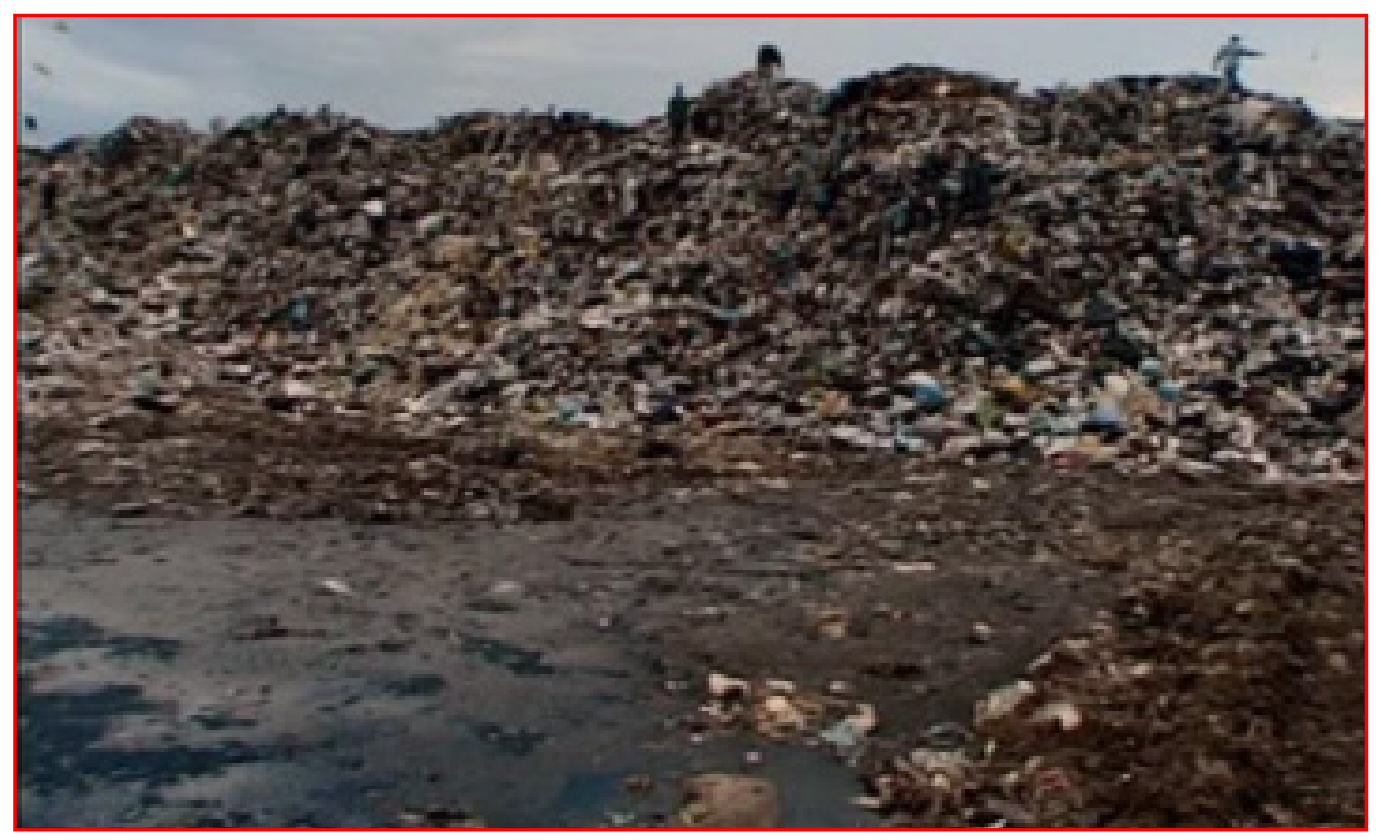

Figura 2. 0 lixão. Fonte: Estamira (2006). 
A potência de vida em Estamira também permite que ela ressignifique esse lugar. Não somente como espaço para o lixo, mas, aos olhos de Estamira, o aterro configura-se como um local de "transbordo" - "Você sabe o que é um transbordo? Bem, toda coisa que enche, transborda!" (Estamira, 2006) -, uma área que recebe os "descuidos":

Isso aqui é um depósito dos restos. Às vezes, é só resto. E às vezes, vem também descuido. Resto e descuido... Quem revelou o homem como único condicional, ensinou ele a conservar as coisas. E conservar as coisa é proteger, lavar, limpar e usar mais o quanto pode. (...) O trocadilo fez duma tal maneira que quanto menos as pessoas têm, mais menosprezam, mais elas jogam fora. Quando menos eles têm. (Estamira, 2006).

Do lixão de Jardim Gramacho, além de construir também sua morada, Estamira retira, do lixo, o seu luxo:

Descarregaram uma coisa muito importante aqui... Que é o de comer... Enlatados, conservas... Amanhã, por causa disso, eu vou preparar uma bela macarronada, entendeu? Macarrão eu já tenho. Deixa eu ver o que é isso. (...) Palmito. Veio uma carga boa. Olha, tá vendo? Eu ponho no molho do macarrão também, tá vendo? E às vezes fica até melhor do que lá no restaurante. Pra quem sabe preparar, né? (EsTAMIRA, 2006).

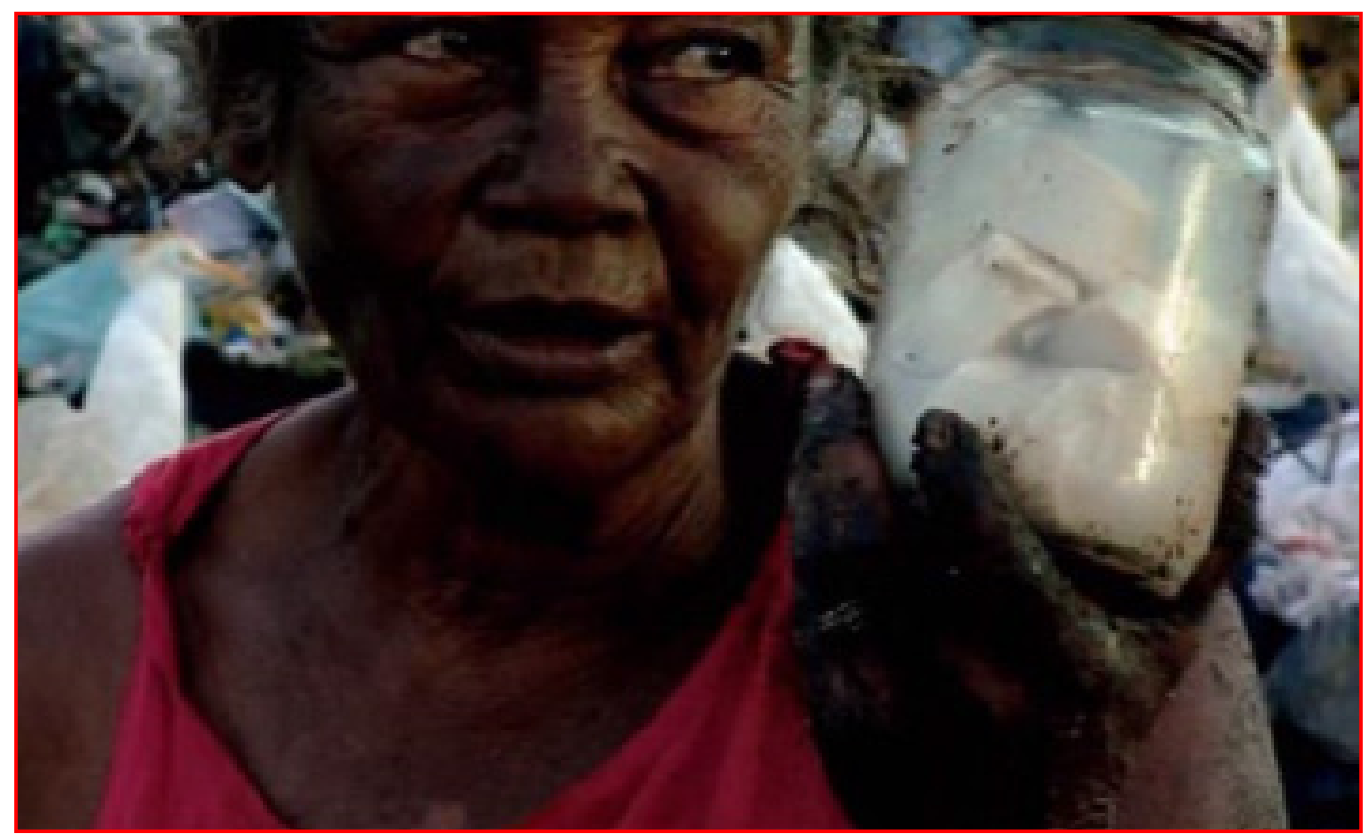

Figura 3. Os achados de Estamira. Fonte: Estamira (2006). 
Dessa forma, o lixão é, para Estamira, um espaço heterotópico. Foucault (2013a) concebe heterotopias como contraespaços: os espaços sociais da diferença, do desvio e da multiplicidade. As heterotopias são os lugares nos quais as incompatibilidades se justapõem: dos restos, Estamira produz o luxo; do repugnante, ela faz emergir sua potência fascinante; do seu amado lixão, "Sr. Cisco Montouro", ela constitui o seu espaço terapêutico, como atesta sua filha mais velha, Carolina: "Depois que ela foi para o lixão lá de Caxias (...), ela melhorou muito, assim, em relação aos distúrbios. Às vezes ela fala certas coisas que parecem até, assim, verdade... Que você fica, que te deixa balançado" (Estamira, 2006). Do aterro enquanto heterotopia, espaço essencialmente de contestação de todos os outros espaços, Estamira cria "uma ilusão que denuncia todo o resto da realidade como ilusão" (Foucault, 2013a, p. 28). Enfim, do lixão, Estamira constitui seu espaço heterotópico de resistência às investidas do governo religioso, familiar e psiquiátrico de sua existência.

\section{"VOCÊ TÁ COM DEUS ENFIADO NO TEU CÚ?"}

O documentário não traz nenhuma autoridade religiosa, como um padre ou pastor evangélico que, através de um poder pastoral, procure evangelizar e dirigir Estamira à alguma espécie de salvação. Há, sim, um ódio e ojeriza a Deus presente nas falas de Estamira e uma tentativa de condução religiosa de sua existência através do seu filho mais velho, Hernani, fiel da Igreja Adventista do Sétimo Dia.

Segundo sua filha Carolina, Estamira era muito religiosa até a ocorrência de dois acontecimentos fatídicos:

Aí foi estrupada uma vez no centro de Campo Grande. Foi estrupada uma segunda vez aqui nessa mesma rua que eu moro. (...) Aí falou, né, que... o cara fez sexo anal com ela e ela gritando: "Para com isso, pelo amor de Deus!". "Que Deus? Esquece Deus!", o estrupador falava pra ela. E fez sexo de todas as formas que quis com ela e depois mandou ela ir: "Se adianta, minha tia, se adianta”. Mandou embora. Aí, chorava, contava esse caso... Ela é muito revoltada, né? Nesse tempo ela não tinha alucinações nenhuma. Não tinha perturbação nenhuma. Muito religiosa. Acreditava que Deus ia... Que aquilo que ela tava passando tipo... Era uma provação. (Estamira, 2006).

Desses eventos traumáticos, parece decorrer uma espécie de desencantamento religioso em Estamira: “Quem fez Deus foi os home!” (Estamira, 2006). E, desde então, uma revolta agressiva e uma ira catártica contra qualquer menção a Deus: 
Já me bateram com pau pra mim aceitar Deus. Mas esse Deus desse jeito, esse Deus deles, esse Deus sujo, esse Deus estrupador, esse Deus assaltante, de qualquer lugar, de tudo quanto é lugar, esse Deus arrombador de casa... Nem a minha carne picadinha de faca, de facão, de qualquer coisa... Eu não aceito, não adianta. (...) Quem quiser me matar pode matar. Não mataram Jesus? Jesus não é bom demais agora depois que ele morreu? Mas eu não, comigo é esquisito. (Estamira, 2006).

Seu filho Hernani acredita que a loucura de Estamira decorre de uma incorporação demoníaca, de uma possessão maligna, o que explicaria suas falas hereges e suas blasfêmias: "É louca, né? Tem o laudo até do médico. Mas, ela espiritualmente, ela parece... a pessoa, acredita ou não acredita, é influência demoníaca, demônios, né?” (EsTAMIRA, 2006). E é a partir dessa concepção religiosa dos males de Estamira que decorre conflitos entre mãe e filho:

Hernani: "Todos nós andávamos desgarrados como ovelhas... cada um se desviava pelo seu caminho, mas o Senhor fez cair sobre eles... a iniquidade de todos nós".

Estamira: Credo em cruz, credo em cruz... Entendeu? O meu ouvido não é privada, otário! (...)

Hernani [se despedindo da mãe após os insultos]: Bom, Shalom Adonai.

Estamira: Vai tomar no rabo! Vai tomar no seu cú! Entra dentro do cú da desgraça, da sua desgraça! Esse pastor todinho é vigarista, vadio e vagabundo. Todos eles! Pior do que os padres! (Estamira, 2006).

\section{"MÃE, SAI DESSA VIDA LÁ DO LIXÃO. LÁ É DIFÍCIL. A PESSOA TEM QUE DORMIR NO RELENTO..."}

A instituição familiar está presente na existência de Estamira. Em vários momentos, o documentário exibe a personagem acompanhada, em sua casa, de seus familiares, os três filhos, os netos e outros agregados. Apesar das resistências e conflitos entre Estamira e seus filhos, há até mesmo cenas de troca de afetos e carinhos, em especial, entre ela e a filha caçula. Já enquanto modalidade de governo que busca dirigir as condutas de Estamira, a família pode ser analisada, no filme, como instância de normalização disciplinar do sujeito e como instrumento do dispositivo psiquiátrico.

No âmbito da família como instituição disciplinadora do indivíduo, seus comportamentos e formas de agir, há uma passagem na qual sua filha Carolina 
narra a insistência da família para que Estamira largasse a vida errante, suja e livre no lixão:

Minha mãe, quando ia trabalhar no Jardim Gramacho, logo quando ela começou, ela passava duas semanas, às vezes uma semana, dormindo ao relento, sei lá como, às vezes em barraca. Às vezes ao relento mesmo lá em cima (...). Depois vinha pra casa, tomava banho, se limpava, toda bonitinha. Ficava perfeita, depois voltava de novo e assim ia. Passou cinco anos assim. Eu e meu irmão, um dia chamamos ela: "Mãe, sai dessa vida lá do lixão... lá é difícil... a pessoa tem que dormir no relento e coisa e tal"... Aí conversamos: "É perigoso achar um negócio que fura você, te contamina”. Ela quis sair. Aí ela foi trabalhar no Mar e Terra. E, quando ela saía dia de sexta-feira, sábado, eu acho, assim... aí, se reunia com os colegas que trabalhava, né... mas iam... ia pra lá beber uma cervejinha e coisa tal. E depois, na hora de ir embora, cada um ia pro teu canto, né? E ela vinha sozinha. (Estamira, 2006).

Domesticada em uma casa e em um trabalho fixo, foram nesses momentos em que voltava sozinha para sua morada que Estamira foi vítima de violência sexual. Na visão da filha Carolina, foi a partir de tais fatos que os transtornos mentais de Estamira afloraram e o lixão do Jardim Gramacho passou a ser seu local, em definitivo, de trabalho e de existência.

Diante dessa vida indisciplinável e em condições precárias, o seu filho mais velho, Hernani, decide retirar sua irmã caçula, Maria Rita, do convívio com a mãe, a despeito dos desejos da criança e de Estamira. No documentário, a mãe adotiva de Maria Rita, Ângela Maria, narra esse momento:

Mais ou menos 12 anos passados, já era motorista e era voluntária num hospital. E aí eu conhecia uma pessoa, uma senhora bacana. E um dia ela chegou lá em casa com essa menina no... era pequenininha assim pela mão, e falou assim: "Eu tenho um presente pra você". Aí, eu falei: "Não vai me dizer, filhinha, que é essa coisinha aí". Ela falou: "É esse bichinho do mato aqui. Tô trazendo pra você cuidar”. Aí eu falei assim: "Da onde é que ela saiu?” Aí ela me contou a história da menina. Que a menina vivia na rua com a mãe... a mãe catava lixo... e... que o irmão dela mais velho não queria aquela vida pra menina. Era muito preocupado com isso e aí ela falou: "Vou marcar uma reunião com os irmãos pros irmãos te conhecerem... porque há um impasse... a irmã quer botar a menina num colégio interno. O irmão achou que ela deve ir para uma casa de família, pra ter um lar”. 
Mas o irmão era mais velho e decidiu que ele é que deveria decidir... E, tudo bem, fiquei com a menina. (EsTAMira, 2006).

Apesar de reconhecer a situação de miséria e de penúria em que viviam no aterro, Maria Rita se ressente de ter sido separada da mãe: "Eu não condeno nenhum dos três, não, mas eu falo mesmo... de vez quando eu tenho mágoa deles. Se minha mãe criou os dois passando fome, eu achava que ela tinha que ter me criado também. Ela tinha condições de ficar comigo, sim!" (Estamira, 2006).

No papel da família como instrumento do dispositivo psiquiátrico - identificando os sujeitos psiquiatrizáveis e conduzindo-os aos mecanismos psiquiátricos - Hernani demonstra também, em um diálogo com a irmã, o desejo de intervir para internar a mãe:

Carolina: Mas ela morrerá feliz se for no meio da rua do que numa clínica lá. Ela sabe... Ela prefere viver dois anos livre do que viver cinco anos... bem, trancada num lugar, você sabe disso.

Hernani: Você não está me entendendo. Isso aí... não vou dizer que ela vai ficar a vida, o resto da vida... o pouco ou, sei lá, o muito que ela tiver. Ela vai ficar até pelo menos ela... entendeu? Ela... ela... eu acho mais o problema dela é sistema nervoso.

Carolina: Mas só que pra ficar lá, teria que ser dopada, amarrada. Pra mim... ele é mais forte que eu nesse caso, se precisar de amarar e dopar é com ele mesmo. Eu já não... Eu acho judiação... (Estamira, 2006).

Outra ocorrência de governo familiar dos comportamentos no qual a família agiu próxima às disposições do poder psiquiátrico efetuou-se na internação da mãe de Estamira em um hospital psiquiátrico. Contra a sua vontade e pressionada pelo então marido, a própria Estamira relata esse episódio:

Primeiro, ele chamou a ambulância pra levar minha mãe. Chamou médico com camisa de força. Aí, o médico falou: "Não, daí não é camisa de força, essa daí não precisa”. Tá bom. Aí ele ficou me atentando, me atentando, me atentando até que fez eu levar a minha mãe lá no Engenho de Dentro. Nós fomos de trem. Coitada da minha mãe, inocente... Tá bom, aí deixei ela lá no hospício... Quando foi na quinta-feira, eu fui lá visitar ela, ela tava com o braço todo roxo. Eu falei: “O que foi isso mãe?”, Ela falou: “Foi o desgraçado”. Deu choque nela, bateu nela, ela tava com o braço roxo. (Estamira, 2006). 
De certa forma semelhante à descrição de Foucault (2006a, 2010a), a família, nessas cenas, apresenta-se psiquiatrizada e patologizando suas irregularidades. Assim, ao livrar-se da sujeição familiar ao marido, Estamira resgata sua mãe do hospício, como conta sua filha Carolina: "A partir do momento que ela largou meu pai... a primeira coisa que ela fez... deixou nós na casa não sei de quem... no morro lá e foi buscar minha avó no dia seguinte. E minha avó sempre seguiu com a gente até morrer." (Estamira, 2006).

\section{"SE EU BEBER DIAZEPAM... SE EU SOU LOUCA, VISIVELMENTE, NATURALMENTE, EU FICO MAIS LOUCA!"}

Estamira submete-se a certas prescrições do governo psiquiátrico de sua existência: há cenas nas quais ela frequenta um CAPS; onde fala a respeito do uso de medicações; em que apresenta disartria - ou "língua enrolada" - e tremores pelos efeitos colaterais de medicamentos; quando lê, com dificuldades, o atestado do seu diagnóstico conferido pelo saber psiquiátrico, "Atesto que Estamira Gomes de Souza... portadora de quadro... é... psicótico de evolução... crônica... alucinações... auditivas... ideias de... influências... discurso místico... deverá permanecer em tratamento psiquiátrico..." (EsTAMIRA, 2006).

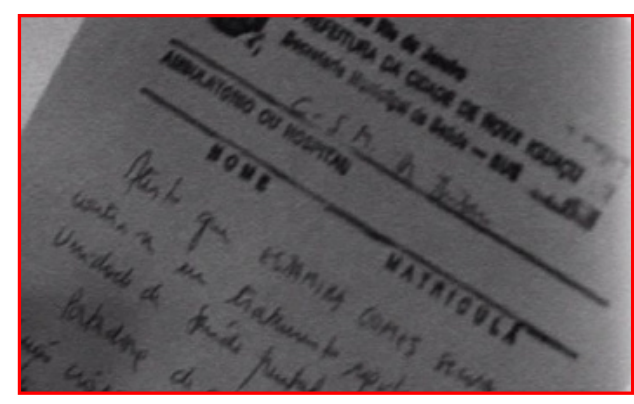

Figura 4. Medicamento com Estamira. Fonte: Estamira (2006).

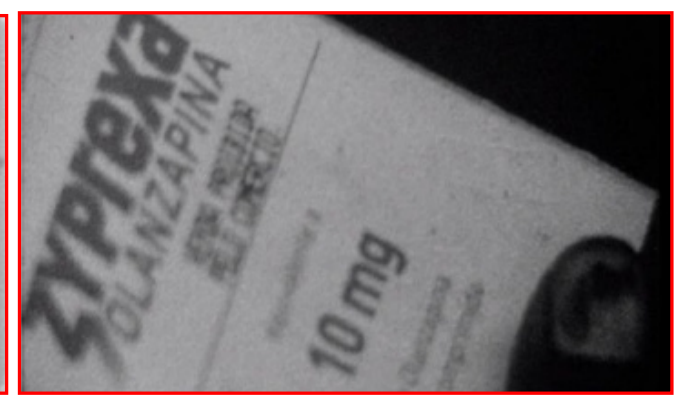

Figura 5. 0 diagnóstico de Estamira. Fonte: Estamira (2006).

No entanto, apesar da sujeição a algumas práticas médicas-psiquiátricas, Estamira também resiste ao assédio de outras investidas do dispositivo psiquiátrico. Em uma passagem do documentário, há o relato de uma tentativa, pelo filho e pelo ex-marido, de internação de Estamira. Mas diferente de quando se curvou ao desejo do marido na internação de sua mãe e agora vivendo no aterro enquanto seu espaço heterotópico, Estamira insurgiu-se de forma violenta, como conta o filho:

Seu Leopoldo, o falecido Leopoldo Fontanive, né? Meu pai de criação. Ele não deu dinheiro nenhum pra ajudar minha mãe, não. Então aí eu fiquei ligando a 
semana toda pra esses hospital, né?...Que trata da cabeça das pessoas, vê se tinha vaga pra poder internar ela, eu tinha combinado com ele assim. Aí fui no hospital lá de Caxias... Fui primeiro com o velho, né? Fui no carro dele. Aí consegui uma ambulância. Aí fomos prá lá pro lixão. Aí, chegou lá, até os bombeiros estavam com medo de encostar a mão nela, porque ela queria morder e tudo, começou a gritar nome de entidades de macumba, né? E daquele jeito, chega espumando, né... parecendo bicho mesmo. (Estamira, 2006).

A respeito das negativas dos hospícios em interná-la, Estamira comenta a atitude do filho, em tom de deboche: "E aquele meu filho ficou contaminado pela terra suja, pelo baixo nível, pelo insignificante, parecendo um palhaço lá, lá dentro do hospital! A coisa mais ridícula!" (Estamira, 2006).

Todavia, é nas críticas ao uso de medicamentos que Estamira apresenta uma resistência mais lúcida, com argumentos até mesmo mais articulados e coerentes. Nesse sentido, por exemplo, Estamira questiona o saber psiquiátrico e a atuação da psiquiatra que lhe atende no CAPS:

A doutora passou remédio pra raiva. [Risos]. (...) Presta atenção nisso. Olha, e ainda mais, eu conheço médico, médico, médico, médico mesmo! Direito, entendeu? Ela é copiadora. Eu sou amigo dela. Eu gosto dela, eu quero bem a ela. Quero bem a todos, mas ela é a copiadora. Eles estão, sabe, fazendo o quê? Dopando, quem quer que seja... com um só remédio! Não pode, o remédio... Quer saber mais do que Estamira? (Estamira, 2006).

Estamira traz, nessa fala, uma crítica ao conhecimento científico, construído e reproduzido nas escolas e na academia: "Vocês não aprendem na escola, vocês copiam. Vocês aprendem é com as ocorrências. Eu tenho neto com 2 anos que já sabe disso. Tem de 2 anos que ainda não foi na escola copiar hipocrisias e mentiras charlatais". Daí, aos seus olhos, os profissionais de saúde serem meros copiadores e repetidores de um conhecimento, prescrevendo - de maneira indiscriminada - o mesmo medicamento para todos: "O tal do diazepam... Não, eles vai lá...só copeia. Uma conversinha qualquer e só copeia e tome...!” (EsTAMIRA, 2006).

Os questionamentos de Estamira dizem respeito também à finalidade, ao seu ver, do uso dos medicamentos:

Fica se viciando... Fica dopando, vadiano... (...) Aí, ó, tudo quanto é remédio que ela passou pra mim eu bebi. As quantia, os limite. Toda coisa tem limite! Esses 
remédio são da quadrilha... da armação... do dopante, pra cegar os home... pra querer Deus... Deus farsário! Entendeu? Esses remédio são dopante pra querer Deus farsário, entendeu? (Estamira, 2006).

O que poderia assemelhar-se a um mero delírio, remédios prescritos por uma quadrilha para os homens buscarem e aceitarem Deus, aproxima-se, de certa maneira, às considerações de Foucault (2006a) sobre o uso de medicamentos no interior dos hospitais psiquiátricos ao longo do século XIX. De acordo com Foucault, a utilização de medicamentos não possuía funções terapêuticas. Funcionava, na realidade, como instrumento disciplinar, como mecanismo de sujeição do individuo à ordem do hospício: "prolongar até o interior do corpo do doente o sistema do regime asilar, o regime da disciplina; era garantir a calma que era prescrita no interior do asilo, era prolongá-la até o interior do corpo do doente" (FoucAult, 2006a, p. 226). Nesse sentido, Estamira parece compreender a utilização de medicamentos psiquiátricos como forma de assegurar um assujeitamento dócil às intervenções de governo - seja religioso, seja familiar, por exemplo - associado a uma perda substancial de autogoverno, como quando reclama de um dos efeitos do uso de medicações: "Desgovernada. Eu tô desgovernada. Sabe o que é uma pessoa desgovernada? Uma pessoa nervosa assim, querendo falar sem poder... agoniada. E eu não sei o que eu faço. Eu já tive pensando em parar um ano sem beber o remédio" (Estamira, 2006).

Enfim, apesar de submeter-se a algumas práticas psiquiátricas, Estamira busca resistir, ainda que de maneira frágil em muitas situações, ao dispositivo psiquiátrico. Nesse sentido, a postura de resistência de Estamira, ainda que com seus desvarios, às tecnologias contemporâneas da psiquiatria assemelha-se à atitude crítica tal como analisada por Foucault (1990, p. 5): ao não querer e não aceitar ser governado de determinada forma, ao não aceitar como um discurso verdadeiro somente por que algo foi proferido por uma autoridade, ao praticar uma espécie de inservidão voluntária.

\section{CONSIDERAÇÕES FINAIS}

Em 2011, cinco anos após o lançamento do documentário, Estamira, aos 70 anos, faleceu em um hospital público - vítima de uma infecção generalizada ocasionada por um ferimento no braço - após esperar por atendimento médico por mais de 5 horas (VAZ, 2011). No interior de uma biopolítica dos anormais/das diferenças, Estamira foi deixada para morrer, literalmente. Contudo, parafraseando Butler (2015, p. 130), graças à construção de um quadro de apreensão de sua 
singularidade pelo documentário, Estamira sobrevive, já que a circulação indefinida de sua imagem e de sua voz permite que sua existência continue a acontecer. E, neste sentido, ela nos lembra, talvez como consolo a aqueles para quem sua morte tornou-se lamentável, que "visivelmente, naturalmente, se eu me desencarnar, eu tenho a impressão que eu serei muito feliz" (EsTAMira, 2006).

Não obstante os limites trazidos pelas operações de poder inerentes à produção cinematográfica e a potência de vida em Estamira que transborda e escapa a este trabalho, procurei averiguar as possibilidades de resistência dessa mulher às formas de governo religioso, familiar e psiquiátrico das condutas. E é no lixão, compreendido como um espaço heterotópico, que Estamira produz - paradoxalmente, visto o seu diagnóstico de psicótica - uma experiência de resistência e de contra-conduta mais articulada e mais consciente contra as práticas atuais da psiquiatria. Experiência de resistência que se realiza com fragilidades: apesar de alguma sujeição, ainda que em precárias condições materiais, trilhando um tênue limiar entre assujeitar-se e adotar uma atitude crítica.

Se Estamira pode ser apresentada como a loucura irredutível que tenta escapar das estratégias de normalizações do poder, o documentário, identificado como de inspiração genealógica, dá voz à desrazão de Estamira, libertando-a do "monólogo da razão sobre a loucura" (FoucAuLT, 2006e, p. 153, grifo do autor) que caracteriza a experiência moderna do louco.

Enfim, como contracondutora e resistência aos governos religioso, familiar e psiquiátrico, Estamira parece que toma, em suas falas e em sua existência, a tarefa proposta por Nietzsche (2009) de realizar a transvaloração de certos preceitos, uma nova valoração de alguns princípios morais: Deus - "trocadilo", "controle remoto superior", "poderoso ao contrário", "Quem fez Deus foi os homem" -; justo e certo - "Me trata com o teu trato que eu te devolvo o teu trato!" -, científico "copiadores" -, trabalho - "Escravo disfarçado de liberto" -, lucidez - "A morte é maravilhosa, a morte é dona de tudo!”.

\section{REFERÊNCIAS}

Amarante, Paulo. Loucos pela vida. A Trajetória da Reforma Psiquiátrica no Brasil. Rio de Janeiro: Editora Fiocruz, 1998.

BAZIN, André. “Ontologia da imagem fotográfica”. In: XAVIER, Ismail (Org.). A experiência do cinema: antologia. Rio de Janeiro: Embrafilme, Edições Graal, 1983, p. 121-128.

ButLer, Judith. Quadros de guerra: Quando a vida é passível de luto? Rio de Janeiro: Civilização Brasileira, 2015. 
CAStro, Edgardo. Vocabulário de Foucault: um percurso pelos seus temas, conceitos e autores. Belo Horizonte: Autêntica, 2009.

Estamira. Direção: Marcos Prado. Rio de Janeiro: Zazen Produções Audiovisuais, 2006. Documentário (115 min). Disponível em: <https://www.youtube.com/watch?

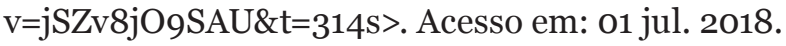

FonTE, Eliane. Da institucionalização da loucura à reforma psiquiátrica: as sete vidas da agenda pública em saúde mental no brasil. Estudos de Sociologia, v. 1, n. 18, 2013. Disponível em: <https://periodicos.ufpe.br/revistas/revsocio/article/ view/235235/28258>. Acesso em: 25 jul. 2018.

Foucault, Michel. História da Sexualidade: A Vontade de Saber, vol. 1. Rio de Janeiro: Edições Graal, 1985.

Vigiar e Punir: nascimento da prisão. Petrópolis: Vozes, 1987.

. O que é a Crítica. Qu'est-ce que la critique? Critique et Aufklärung. Bulletin de la Société Française de Philosophie, v. 82, n. 2, p. 35-63, 1990. LAFETÁ, Gabriela (Trad.); Nascimento, Wanderson F. (Rev.). Disponível em: <http://www.unb.br/fe/tef/ filoesco/foucault/critique.html>. Acesso em: 15 jul. 2018.

"O sujeito e o poder". In: DreYFus, Hubert L.; Rabinow, Paul. Michel Foucault: uma Trajetória Filosófica. Para Além do Estruturalismo e da Hermenêutica. Rio de Janeiro: Forense Universitária, 1995, p. 231-239.

. Em Defesa da Sociedade: curso no Collège de France (1975-1976). São Paulo: Martins Fontes, 1999.

"A vida dos homens infames". In: Foucault, Michel. Ditos \& escritos: estratégia, poder-saber. Rio de Janeiro: Forense Universitária, 2006a, p.203-222.

. "A governamentalidade”. In: Foucault, Michel. Ditos \& escritos: estratégia, poder-saber. Rio de Janeiro: Forense Universitária. 2006b, p. 281-305.

"Omnes et singulatim: uma crítica da razão política". In: Foucault, Michel. Ditos \& escritos: estratégia, poder-saber. Rio de Janeiro: Forense Universitária; 2006c, p. 355-385.

O Poder Psiquiátrico: curso no Collège de France (1973-1974). São Paulo: Martins Fontes, 2006d.

"Prefácio". In: Foucault, Michel. Ditos \& Escritos: estratégia, poder-saber. Rio de Janeiro: Forense Universitária, 2006e, p. 152-161. Segurança, território, população: curso no Collège de France (1977-1978). São Paulo: Martins Fontes, 2008. Os Anormais: curso no Collège de France (1974-1975). São Paulo: Martins Fontes, 2010a. 
. Crise da medicina ou crise de antimedicina, Revista Verve, São Paulo, Nu-Sol/ PUC-SP, nº 18, p. 167-194, 2010b.

O corpo utópico: As heterotopias. São Paulo: n.1 edições, 2013 a.

O governo de si e dos outros: curso no Collège de France (1982-1983). São Paulo: Martins Fontes, 2013b.

"O nascimento da medicina social". In: Foucault, Michel. Microfísica do poder. Machado, Roberto (Org.; Trad). Rio de Janeiro: Edições Graal, 2016a, p. 143-170. "A política da saúde no século XVIII". In: Foucault, Michel. Microfísica do poder. Machado, Roberto (Org.; Trad). Rio de Janeiro: Edições Graal, 2016b, p. 296-317.

"Sobre a história da sexualidade". In: Foucault, Michel. Microfísica do poder. Machado, Roberto (Org.; Trad). Rio de Janeiro: Edições Graal, 2016c, p. 363-406.

. A coragem da verdade: curso no Collège de France (1983-1984). São Paulo: Martins Fontes, 2017.

Machado, Roberto. "Introdução: Por uma genealogia do poder". In: Foucault, Michel. Microfísica do poder. MACHAdo, Roberto (Org.; Trad). Rio de Janeiro: Edições Graal, 2016, p. 7-34.

Mansanera, Adriano. Parrhesía e loucura no exemplo de Estamira. Tese (Doutorado em Filosofia). Florianópolis, Universidade Federal de Santa Catarina, 2015.

Martín, Maria. A 30 quilômetros de Ipanema, a vida passa com menos de três reais por dia. El País Brasil, São Paulo, 14 dez. 2017. Disponível em: <>. Acesso em: 28 jul. 2018. Nichols, Bill. Introdução do documentário. Campinas: Papirus, 2008.

Nietzsche, Friedrich. Genealogia da moral: uma polêmica. São Paulo: Companhia das Letras, 2009.

Pelbart, Peter Pál. Biopolítica. Sala Preta, Brasil, v. 7, p. 57-66, nov. 2007. Disponível em: <http://www.revistas.usp.br/salapreta/article/view/57320>. Acesso em: 10 jul. 2018. . "Introdução". In: FernANDEs, Ricardo (Org.). Estamira - fragmentos de um mundo em abismo. São Paulo: n-1 edições, 2013, p. 4-7.

Estamos em guerra. São Paulo: n.1 edições, 2017.

Prado, Marcos. Jardim Gramacho. Rio de janeiro: Argumento, 2004.

VAz, Juliana. Estamira Gomes de Souza (1941-2011). Folha de São Paulo, São Paulo, 30 jul. 2011. Disponível em: <http://www1.folha.uol.com.br/fsp/cotidian/ff3007201115. htm>. Acesso em: 02 ago. 2018.

Recebido: 10/10/2018 | Aprovado: 09/03/2020 